\title{
FASILITAS PELATIHAN BERSELUNCUR DAN PARKOUR
}

\author{
William Wongso" ${ }^{1)}$, Maria Veronica Gandha ${ }^{2)}$ \\ 1) Program Studi S1 Arsitektur, Fakultas Teknik, Universitas Tarumanagara, \\ williamwong19968@yahoo.com \\ 2) Program Studi S1 Arsitektur, Fakultas Teknik, Universitas Tarumanagara, mariag@ft.untar.ac.id
}

\begin{abstract}
Abstrak
Jakarta termasuk kota wisata yang kaya dan menawarkan destinasi yang luar biasa lengkap. Mulai dari wisata sejarah, kuliner, alam, ekstrem, hingga belanja. Sebagai pusat pemerintahan sejak era sebelum merdeka, Jakarta menyimpan banyak sekali kekayaan sejarah yang kini dapat kita nikmati sebagai objek wisata. Jakarta juga sangat penting bagi Indonesia, karena merupakan ibukota serta pusat pemerintahan dan perekonomian dari Republik Indonesia, sehingga tentu keoptimalan dalam menopang kegiatan di dalamnya sangatlah diharapkan. Tujuannya adalah agar segala aktivitas di kota ini dapat tertopang dengan baik. Segala aktifitas kegiatan yang ada di Jakarta akan baik apabila warga masyarakat memiliki kesehatan yang baik juga. Akan tetapi, menurut Data Badan Pusat Statistik menunjukkan bahwa pada 2017, jumlah penduduk Indonesia yang rutin berolahraga belum mencapai sepertiga dari total penduduk, hanya 27,61 persen penduduk Indonesia yang melakukan olahraga minimal sekali dalam seminggu. Dapat dikatakan bahwa dari 100 penduduk Indonesia berumur 12 tahun ke atas, hanya sekitar 27 orang yang aktif berpartisipasi dalam kegiatan olahraga, sedangkan 73 orang lainnya tidak rutin berolahraga. Selain itu masalah yang terdapat di Jakarta yang lainnya ialah polusi udara. Jakarta menduduki peringkat lima, kota dengan kualitas udara terburuk di dunia (September 2017). Empat kota lainnya adalah Beijing (Cina)-urutan pertama, yang diikuti oleh Santiago (Cile), Kolkata (India), dan Hongkong (Cina). Pemeringkatan tersebut berdasarkan indeks kualitas udara real-time pada aplikasi Airvisual. Perancangan pembangunan Architourism Fasilitas Pelatihan Berseluncur dan Parkour dapat membawa pengaruh khususnya bagi masyarakat Jakarta untuk berolahraga dan mengurangi polusi udara dengan menggunakan metode transportasi alternatif seperti sepeda, skateboard atau sepatu roda.
\end{abstract}

Kata kunci : Kesehatan, Olahraga, Transportasi Alternatif, Wisata

\begin{abstract}
Jakarta is a tourism city and offers exceptionally complete destinations. Starting from historical tourism, culinary, natural, extreme, to shopping. As the center of government since the era before independence, Jakarta has a lot of wealth of history that we can now enjoy as a tourist attraction. In addition, Jakarta is also a city that is very important for Indonesia, because Jakarta is the capital and center of government and economy of the Republic of Indonesia, so certainly optimism in supporting the activities that take place in it is highly expected. The goal is that all activities in this city can be supported properly. All activities in Jakarta will be good if the citizen has good health too. However, according to Central Statistics in Indonesia shows that in 2017, the number of Indonesians who regularly exercise has not reached one third of the total population, only 27.61 percent of the Indonesian population exercises at least once a week. This means that out of 100 Indonesians aged 10 years or over, only about 28 people actively participate in sports activities, while 72 other people do not exercise regularly. In addition, the other problem found in Jakarta is air pollution. Jakarta is ranked fifth in the city with the worst air quality in the world (September 2017) Four other cities, which have the worst air quality are Beijing (China) - in the first place, followed by Santiago (Chile), Kolkata (India), and Hong Kong (China). The city ranking is based on the realtime air quality index in the Airvisual application. Designing the construction of Architourism Skating and Parkour Training Facilities can have an influence especially for citizen of Jakarta to exercise regulary and reduce air pollution by using alternative transportation methods such as bicycles, skateboards or roller skates.
\end{abstract}

Keywords: Alternative Transportation. Exercise, Health, Tourism 


\section{PENDAHULUAN}

Jakarta sebagai kota metropolitan merupakan ibukota serta pusat pemerintahan dan perekonomian dari negara Republik Indonesia. Jakarta juga termasuk kota wisata yang kaya dan menawarkan destinasi yang luar biasa lengkap. Mulai dari wisata sejarah, kuliner, alam, ekstrem, hingga belanja. Sebagai pusat pemerintahan sejak era sebelum merdeka, Jakarta menyimpan banyak sekali kekayaan sejarah yang kini dapat kita nikmati sebagai objek wisata.

Akan tetapi, Jakarta sebagai kota penting tidak terlepas dari berbagai permasalahan. Salah satu Masalah yang terdapat di Jakarta sampai sekarang ialah polusi udara. Jakarta menduduki peringkat lima kota dengan kualitas udara terburuk di dunia(September 2017) Empat kota lainnya, yang memiliki kualitas udara paling buruk adalah Beijing (Cina) -pada urutan pertama, yang diikuti oleh Santiago (Cile), Kolkata (India), dan Hongkong (Cina).Pemeringkatan kota tersebut berdasarkan indeks kualitas udara real-time pada aplikasi Airvisual. Fenomena ini dapat terlihat jelas dari banyaknya pengguna mobil atau kendaraan pribadi dibandingkan menggunakan transportasi umum atau publik karena banyaknya permasalahan seperti penyalahgunaan trotoar, kurangnya infrastruktur atau fasilitas pejalan kaki maupun transportasi umum.

Mengacu terhadap teori Achitourism diharapkan rancangan design mampu menyikapi fenomena tersebut dimana mengurangi permasalahan-permasalahan dan menaikan nilai perekonomian khususnya pariwisata, nilai kesehatan, aktifitas sosial yang positif, edukasi mengenai olahraga skate dan fasilitas pelatihan berseluncur dan parkour sekaligus mendorong masyarakat untuk menggunakan transportasi alternatif.

\section{KAJIAN LITERATUR}

Architourism merupakan sebuah pengertian yang menggabungkan 2 pengertian yang berasal dari arsitektur (bangunan) dan turisme (pariwisata) yang mempunyai makna sebagai bangunan untuk pariwisata. Architourism yang ada di suatu tempat dapat berbeda beda efeknya seperti pariwisata di Barcelona, Jerman, Paris dan Beijing. Hal ini dikarenakan bangunan pariwisata yang mereka bangun adalah bangunan kontemporer atau bangunan zaman modern. yang memperlihatkan gambaran dan menaikan "posisi" dalam hal persepsi kepada dunia kemudian.menarik perhatian dan investasi dari segi pariwisatanya masingmasing. Efek bilbao adalah istilah yang dipakai untuk menggambarkan efek dari sebuah museum Guggenheim yang mengangkat perekonomian kota (hotel, restoran, toko dan transportasi) secara tidak sengaja. Menurut Frank Gehry sendiri beliau tidak menyangka bahwa karyanya dapat memberi pengaruh sebesar ini terhadap dunia, ia berasumsi bahwa Gugenheim museum adalah sebuah pecahan kecil yang ada di kota bilbao, tentunya tanpa ada infrastruktur lain yang mendukung tidak akan terjadi efek bilbao. Secara garis besar diperlukan manajemen dan regenerasi yang dibutuhkan kota bilbao seperti penambahan hotel, restoran dan transportasi.

Pariwisata adalah perjalanan atau perpindahan orang ke suatu tempat lain untuk mencari kepuasan mengetahui sesuatu, memperbaiki kesehatan, menikmati olahraga atau istirahat, menunaikan tugas, berziarah dan lain-lain dan tidak menetap (sementara) serta berkaitan dengan perekonomian di suatu negara, kota atau daerah tersebut; Pariwisata adalah kegiatan melakukan perjalanan dengan tujuan mendapatkan kenikmatan, mencari kepuasan, mengetahui sesuatu, memperbaiki kesehatan, menikmati olahraga atau istirahat, menunaikan tugas, berziarah dan lain-lain James J. Spillane (1982)

Pariwisata olahraga adalah suatu perjalanan orang-orang yang bertujuan untuk melihat atau menyaksikan suatu pesta olahraga di suatu tempat atau negara tertentu atau ikut berpartisipasi dalam kegiatan olahraga itu sendiri. Pariwisata untuk olahraga (Sport tourism) menurut Spillane (1987:30) dapat dibagi dalam dua kategori yaitu Big sport events (peristiwaperistiwa olahraga besar seperti Olympic games, kejuaraan ski dunia, kejuaran tinju dunia dan olahraga lainnya yang menarik perhatian tidak hanya pada olahragawannya sendiri tetapi juga 
ribuan penonton atau penggemarnya) serta Sporting tourism of the practicioners (pariwisata olahraga bagi mereka yang ingin berlatih dan mempraktekkan sendiri seperti pendakian gunung, olahraga naik kuda, berburu, memancing dan lain sebagainya).

Olahraga adalah suatu bentuk kegiatan fisik yang dapat meningkatkan kebugaran jasmani yang dilakukan dengan maksud untuk memelihara kesehatan dan memperkuat otot - otot tubuh seperti sistem kardiovaskular, sistem respirasi, sistem ekskresi, sistem saraf yang dapat mencegah resiko terjadinya penyakit tidak menular seperti penyakit pembuluh darah, diabetes, kanker dan psikologis dengan mengurangi ketegangan-ketegangan pada pikiran; Sport atau olahraga merupakan kegiatan - kegiatan yang bersifat fisik dengan mengandung sifat permainan serta berisi perjuangan dengan diri sendiri dan orang lain atau konfrontasi dengan unsur alam. (Lutan, 1992).

Adapun pemilihan 3 olahraga didasari dari media alternative transportasi berupa Parkour, skateboard dan sepeda untuk mengurangi permasalahan yang ada di Jakarta dan menaikan nilai perekonomian khususnya pariwisata dan nilai kesehatan. Parkour mempunyai arti bergerak atau teknik berpindah tempat dari tempat satu ke tempat yang lain dengan cepat dan mengedepankan keindahan bergerak dan di Imbangi dengan kemampuan bergerak dari tubuh itu sendiri. Skateboard adalah kegiatan olahraga seluncur yang melibatkan mengendarai dan menunjukan trick-trick menggunakan papan skate. Skateboarding sendiri dapat dikatakan sebagai aktifitas rekreasi, pertunjukan seni, hiburan dan metode transportasi.

Bersepeda merupakan salah satu moda transportasi darat, kemudian sepeda dijadikan sebagai kegiatan rekreasi atau olahraga. Sepeda pertama kali diperkenalkan pada abad ke-19 Masehi. Sepeda dapat dilakukan di berbagai macam medan, misalnya perbukitan, medan yang terjal atau jalan yang rata baik di pedesaan maupun di perkotaan. Skatepark adalah sebuah fasilitas olahraga yang dibuat khusus untuk olahraga seperti papan luncur dan bmx freestyle. Pada dasarnya semua skatepark harus mempunyai area untuk pemula. Area pemula adalah bagian dimana seseorang yang belum bisa bermain papan luncur atau belum berpengalaman dapat berlatih dalam lingkungan yang lebih terkontrol. Ukuran untuk area pemula kira-kira antara 463 sampai 743 m2 sedangkan untuk area yang sudah mahir kira-kira antara 930-1860 $\mathrm{m} 2$ dengan elemen-elemen street course yang berupa ledge, tangga dan rail yang berupa pagar atau pegangan tangga. Ukuran street course kira-kira antara 930-1860 m2. Dengan standar peralatan seperti : Box, Launch Ramp, Fun Box, Half Pipe Ramp
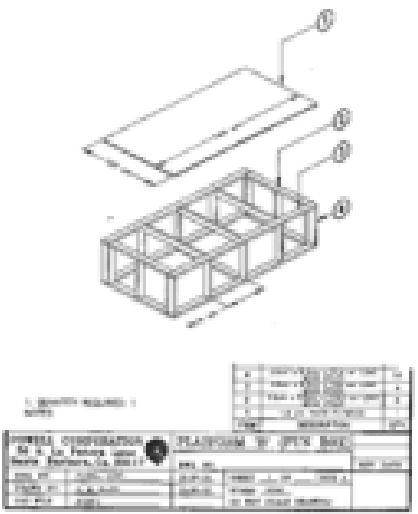

Gambar 1. Instalasi Box

Sumber: Skateparkguide.com , 2018 


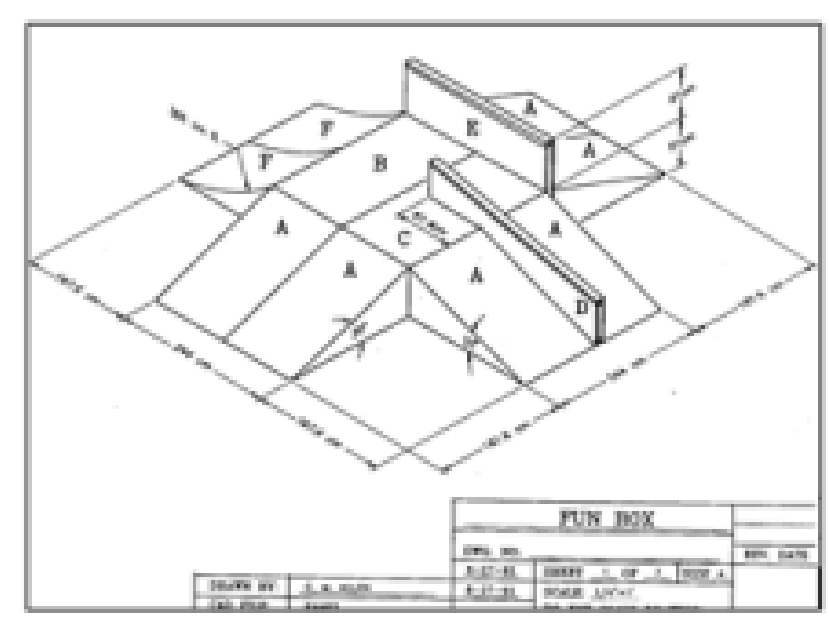

Gambar 2. Gambar Instalasi Launch Ramp Sumber: Skateparkguide.com, 2018

\section{METODE}

Dalam perancangan ini, perancang menggunakan dua metode untuk menjawab setiap permasalahan dan mencapai tujuan dari perancangan ini, yaitu: Studi Literatur sebagai pedoman dalam menentukan dasar standar sebuah ruang skatepark, konstruksi dan instalasi instalasinya; Studi kasus, dilakukan dengan pengamatan terlebih dahulu terhadap objek yang berkaitan dengan tema penulisan dan survey lapangan atau observasi.

\section{DISKUSI DAN HASIL}

Dengan permasalahan polusi udara dan nilai kesehatan yang rendah sebagai latar belakang pembuatan proyek, maka diusulkan proyek wisata olahraga dengan konsep "Arsitektur + Olahraga" melalui pelatihan sepeda, skateboard, sepatu roda dan parkour untuk mendorong orang untuk menggunakan media transportasi alternatif yang berlokasi di wilayah kota tua, kelurahan Pinangsia Jakarta Barat yang bernama Fasilitas Pelatihan Berseluncur dan Parkour .

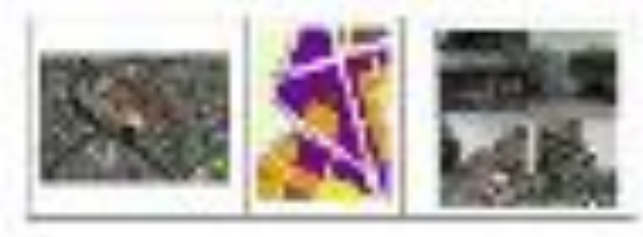

Gambar 4. Lokasi Site

Sumber: Google Map dan RDTR Jakarta Barat,2014

Deskripsi proyek adalah luas lahan $\pm 6.000 \mathrm{M}^{2}$, termasuk ke dalam zonasi K.2 (KDB, 75; KLB, 3.00; KB, 4; KDH, 30; KTB, 55) dan S.6 (KDB, 55; KLB, 3.00; KB, 4; KDH, 30; KTB, 55), tanah milik Pemerintah, tanah kosong (dijadikan tempat parkir), site dilalui kendaraan jalan Pintu Besar Selatan arah Gajah Mada - Kota Tua, berada di ruas jalan utama. Dengan program-program dibawah ini.

\section{Skating Room}

Area tempat berlatih berseluncur yang dapat digunakan baik bagi pengguna skateboard, Sepatu roda atau BMX (Bicycle Moto-Cross) yang kemudian terdapat rintangan seperti Ramp, vert wall, quarter pipe, stair, bank, fun box, flat rail dan kinked rail.

\section{Ruang Parkour}

Area tempat berlatih parkour yang terdapat pipa pull up, tali tambang yang diikat, boxes, 
inclined wall, vertical wall, stair, quarter pipe.

\section{Klinik}

Pelayanan kesehatan (spesialistik tulang) dan pertolongan pertama apabila harus dilanjutkan ke rumah sakit.

\section{Kantin/ Cafe}

Tempat untuk makan-minum sekaligus beristirahat.

\section{Ruang Terbuka}

Taman yang berfungsi untuk mengurangi polusi udara yang ada di sekitar site dan dapat diajdikan tempat berkumpul untuk orang yang berada di daerah site tersebut. Yang kemudian juga terdapat skateboard park yang bersifat luar ruangan (outdoor).

\section{Konsep dan tema}

Bangunan yang "moveable" bagi pengunjung, fleksibel dan dinamis dengan konsep memudahkan orang untuk berpindah dari satu titik ke titik lain sehingga pedestrian circulation menjadi fleksibel. Menyatu dengan landscape sehingga massa tidak seperti bangunan masive karena tujuan dari bangunan Architourism ini untuk mengurangi polusi udara sehingga perbandingan dengan ruang terbuka yang nantinya digunakan untuk sirkulasi udara, aktifitas outdoor (skatepark, free running) dan penyesuaian sirkulasi pejalan kaki.

\section{Tema Heksagonal}

Heksagonal adalah bentuk ruang geometri yang terbentuk atas 6 sisi dan masing sisinya mempunyai sudut 60 derajat. Bentuk hexagonal yang simetris, jika digabungkan akan menghasilkan kombinasi ruang yang sempurna, yaitu tidak menghasilkan ruang-ruang sisa. Selain itu, bentuk ini juga lebih menghemat material jika disusun dengan bentukan heksagonal lainnya.

Dengan mengunakan tema heksagonal dalam perancangan design didasari dari pemikiran bentuk pola konektifitas yang kuat dan tehubung antara satu modul dengan modul lainnya, ide tersebut kemudian diperluas tidak hanya dalam bentuk landscape (horizonal) tetapi juga bentuk bangunan (vertikal).

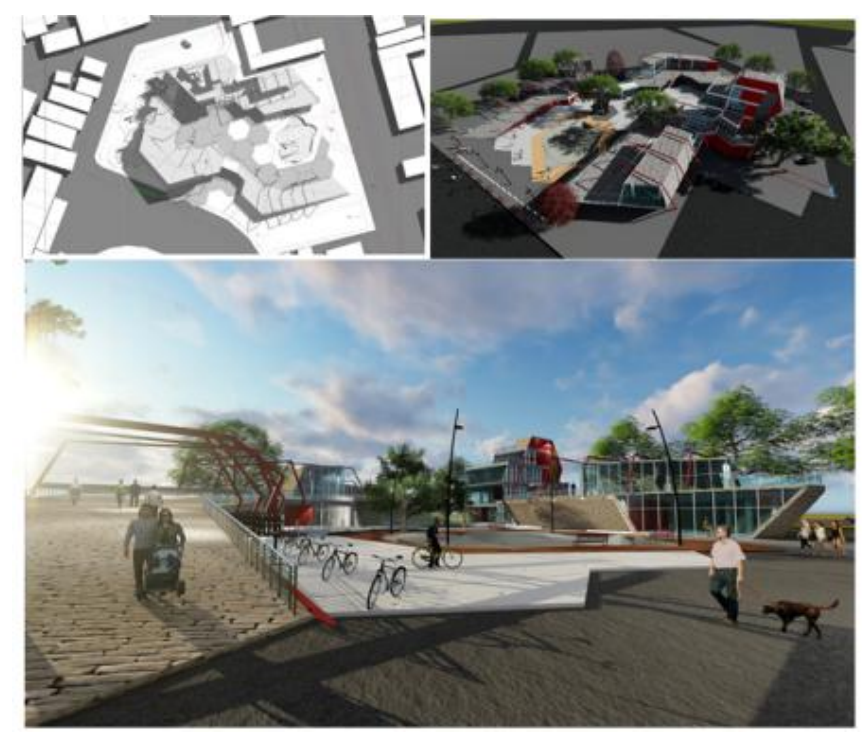

Gambar 5. Pengaplikasian Tema Heksagonal dan Bangunan yang "Moveable" ke Design Blockplan ( Kiri Atas) Perspektif Bird Eye View (Kanan Atas) Perspektif Human Eye View (Bawah) Sumber: Dokumen Pribadi,2019 


\section{Hasil rancangan}

Berikut hasil rancangan berupa denah, tampak, potongan yang terbentuk dengan menggunakan tema heksagon baik secara horizintal (landscape) dan vertikal (bangunan).

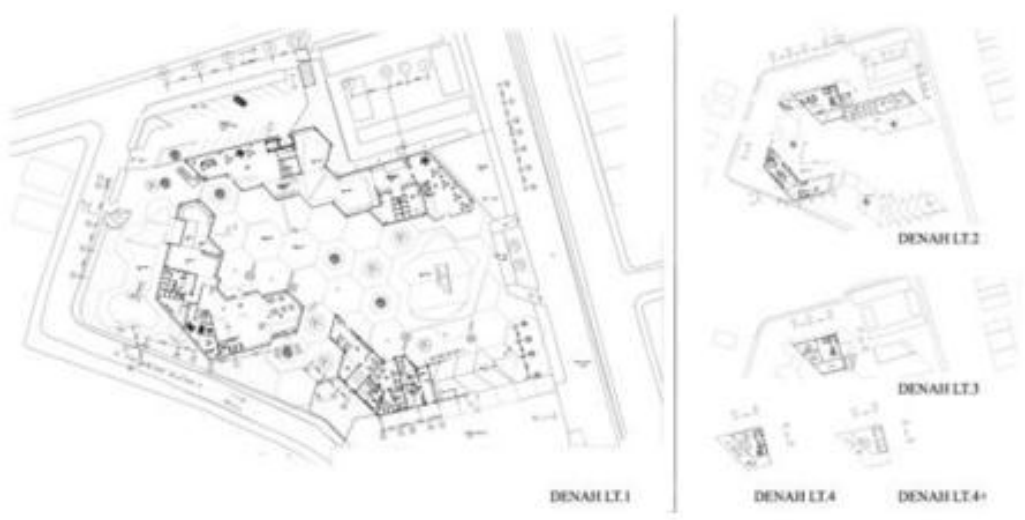

Gambar 6. Pengaplikasian Tema Heksagonal Denah Lantai $1-4$ Berisi Program-Program Bangunan Fasilitas Pelatihan Berseluncur dan Parkour Sumber: Dokumen Pribadi, 2019

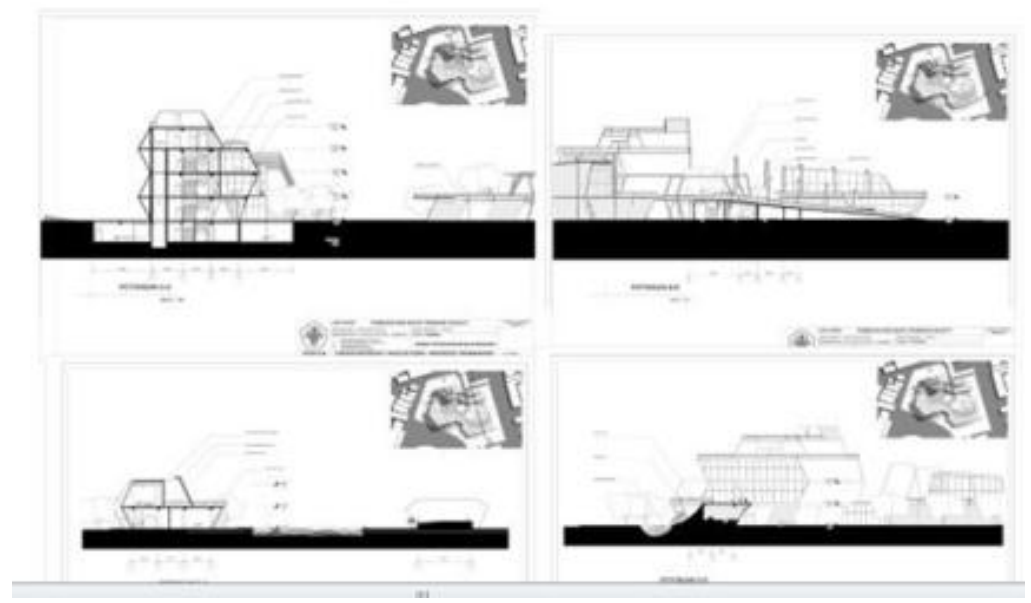

Gambar 7. Potongan A-A, B-B, C-C dan D-D

Sumber: Dokumen Pribadi,2019

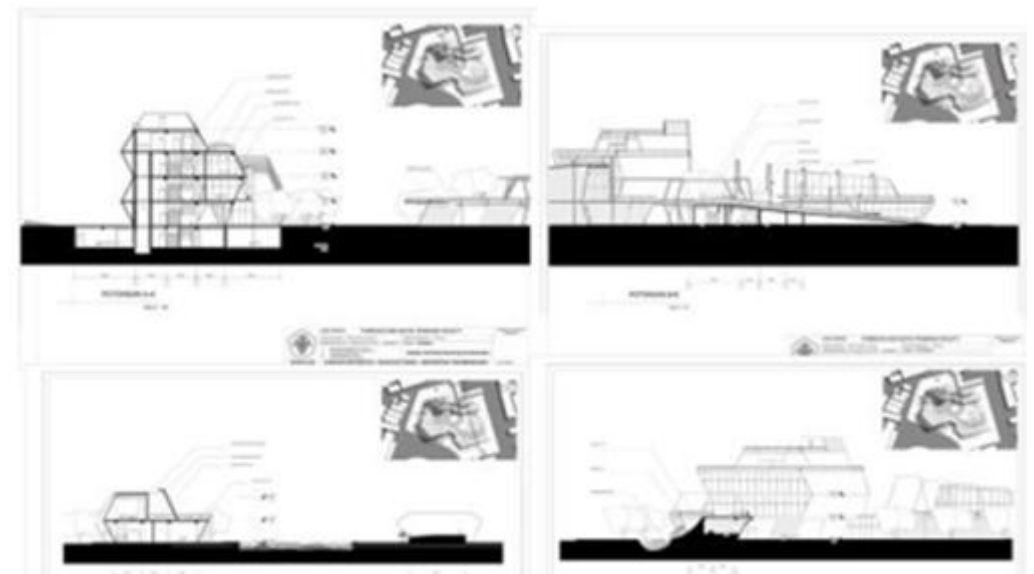

Gambar 8. Penampilan Tampak Bangunan Sumber : Dokumen Pribadi, 2019 


\section{KESIMPULAN DAN SARAN}

Dapat disimpulkan bahwa proyek Achitourism, Parkour and Skate Training Facility dapat menaikkan nilai kesehatan masyarakat lokal/sekitar dengan cara membuka ruang terbuka, sekaligus mendorong masyarakat untuk menggunakan transportasi alternatif terutama sepeda dan skateboard sehingga diharapkan mampu mengurangi polusi udara, menaikkan nilai wisata dan perekonomian di wilayah tersebut.karena akan dikunjungi oleh turis baik wisatawan lokal maupun asing (magnet tourism), penyebaran titik lokasi pelatihan berupa "skatepark" semakin merata sekaligus mengedukasi warga masyarakat Jakarta khususnya olahraga skate dan parkour.

\section{UCAPAN TERIMA KASIH}

Saya mengucapkan terima kasih kepada masyarakat sekitar kawasan Kota Tua, Jakarta dan orang-orang yang telah membantu saya dalam proses pencarian data, teman-teman dan orang tua.

\section{REFERENSI}

Specht, J. (2014). Architectural Tourism. Munich : Springler Gabler.

Moore, R. (2017). The Bilbao Effect: How Frank Gehry Guggenheim Museum Started a Global

Craze. TheGuardian.com.

Peta Zonasi Kecamatan Tamansari. (2014). In Rencana Detail dan Tata Ruang. Jakarta:

Peraturan Provinsi Daerah Khusus Ibukota Jakarta.

Yoeti, O. (1996). Pengantar Ilmu Pariwisata. Bandung.: Angkasa.

Http:// Skateparkguide.com / diakses pada 19 Agustus 2018, pukul 14:00 WIB

Http:// data.jakarta.go.id/group/kesehatan /diakses pada 9 Juli 2018, pukul 10:00

WIB 